ENTREPRENEURSHIP AND SUSTAINABILITY ISSUES

ISSN 2345-0282 (online) http://jssidoi.org/jesi/

2020 Volume 7 Number 3 (March)

http://doi.org/10.9770/jesi.2020.7.3(37)
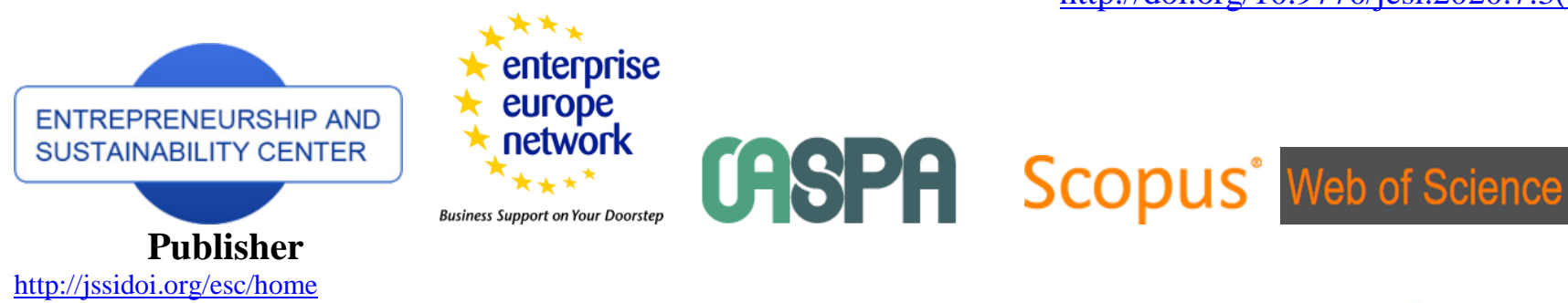

http://jssidoi.org/esc/home

Business Support on Your Doorstep

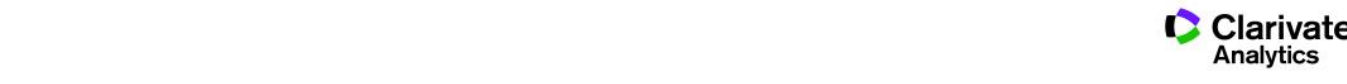

\title{
THE IMPORTANCE OF ACCOUNTING AND REPORTING IN THE PROCESS OF FINANCE MANAGEMENTIN A BASIC UNIT OF THE TERRITORIAL GOVERNMENT
}

\author{
Monika Wakuła \\ Siedlce University of Natural Sciences and Humanities, Faculty of Social Sciences, Żytnia Street 17/19, 08-110 \\ Siedlce, Poland \\ E-mail: monika.wakula@uph.edu.pl
}

Received 12 August 2019; accepted 18 December 2019; published 30 March 2020

\begin{abstract}
Currently units of the territorial government function in a quickly changing environment. To be able to survive and work in accordance with their mission, they must undertake a wide range of decisions concerning finance management. In order to do it accurately and minimise the risk of a badly made decision, people responsible for the management should have access to full and reliable information. The information derives from the accounting system and in particular from its last stage - reporting. The aim of the article is an attempt to find the answer whether accounting and reporting applied in basic units of the local government provides essential information to make appropriate decisions, especially the financial ones. To fulfill the goal, the analysis of literature and legal acts was conducted. In addition, empirical studies were carried out in communes of Siedlce- subregion and Ostrołęka subregion.
\end{abstract}

Keywords: reporting; accounting; commune; management

Reference to this paper should be made as follows: Wakuła, M. 2020. the role of stakeholders in shaping smart solutions in Polish cities Entrepreneurship and Sustainability Issues, 7(3), 1996-2011. https://doi.org/10.9770/jesi.2020.7.3(37)

JEL Classifications: M400, M410, M480

\section{Introduction}

Social and economic transformations, which took place in Poland, led to the shift from centrally-planned economy to the market economy. As a result of that, there were numerous changes within the scope of systemic relation of the state and its bodies, both private and state ones. At the same time, economic transformations resulted in the fact that some economic, legal and social problems were revealed through the whole country as well as in local communities (Wartalska, 2007). The problems were to be solved by central authorities with the help of the territorial government whose basic unit was said to become a commune. Its position in the system of power and economy forces a particular care and attention paid to rational use of available resources in the widely understood interest of the local community.

One of the main areas of general management is finance management which may be defined as a sequence of financial decisions made in order to manage the commune resources in a rational way. 


\section{ENTREPRENEURSHIP AND SUSTAINABILITY ISSUES}

ISSN 2345-0282 (online) http://jssidoi.org/jesi/

2020 Volume 7 Number 3 (March)

http://doi.org/10.9770/jesi.2020.7.3(37)

People responsible for making decisions should have access to full and reliable information. The demand for financial information is fulfilled by the information system such as accounting, and in particular, its last stage financial reporting. 'Success' of a given unit of the territorial government is in a he extent dependent on the quality of information derived from the system and its proper use. Thus, there has been observed a significant increase in the significance of accounting as an information system used in basic units of the local government. Accounting is a tool which enables us to increase the efficiency and effectiveness of the management of communes.

Due to the facts described above, the article contains criticism concerning rules of accounting and reporting existing in Polish communes.

The aim of the article is an attempt to find the answer whether accounting and reporting applied in basic units of the local government provides essential information to make appropriate decisions. The article will be also an attempt to indicate a modification to the way of cost records in basic units of the territorial government, which may be the first step to ensure usefulness of information in the process of management and as a result to the reduction of wasting public funds.

The fulfillment of such a goal will be performed on the basis of the analysis of the subject literature as well as on the empirical studies conducted in Siedlce subregion and Ostrołęka subregion.

After analysing the subject literature and practices applied in basic units of the territorial government, the following thesis has been formulated: present accounting and reporting used in communes do not provide enough information for managerial purposes and are conducted only because it is needed as a fulfillment of some legal requirements.

The problems described in the article are similar to the research conducted by numerous authors. Studies concerning the issue of using accounting for managerial purposes in units of the territorial government were started in the 1990s by prof. A. Jaruga $(1988,1990,2007,2001)$. The subject was also analysed by such authors as B. Filipiak (2009), A. Zysnarska (2010), M. Dylewski (2011). Foreign writers dealing with the issue included Nogueira S.P.S Jorga, Oliwier M.C. (2013), Efendi R., Dewi F.G, Gamayuni R.R. (2018), Cohen S., Karayzimans S. (2017), Andriani Y., Kober R. (2010), Agriyanto R., Rohman, A., Ratmono D., Ghozali, I. (2016), El Idrissi, N. E. A., Ilham Zerrouk, I., Naoual Zirari, N., Monni, S. (2020).

\section{Literature review}

Having departed from the centrally-planned economy, Poland had to create new accounting for the needs of the free-market economy. On 1st January 1995, a legal act of 24th September 1994 on accounting was introduced and it has been valid until today. It is a very important act that regulates functioning of accounting in all economic units, including communes. Obviously, due to the specifics of the units of the territorial government, including communes, reporting of the group units must be additionally determined by the legal provisions within the scope of public finance. The law valid in this scope is the Act of 27 August 2009 on public finance. Additionally, the regulations were improved by Regulation of the Minister of Development and Finance of 13 September 2017 on accounting and charts of accounts for the state budget, budgets of units of the territorial government, budgetary units, Local Government Budget Divisions, state-run specific purpose funds and state budget units based outside the Republic of Poland. The legal act defines detailed rules of accounting and charts of accounts for units of the sector of public finance. 


\section{ENTREPRENEURSHIP AND SUSTAINABILITY ISSUES}

ISSN 2345-0282 (online) http://jssidoi.org/jesi/

2020 Volume 7 Number 3 (March)

http://doi.org/10.9770/jesi.2020.7.3(37)

Accounting of the budget sector fully applies to the same principles and fulfills the same functions that are performed in the private sector, however, the environment in which it functions is distinct by nature and the events and transactions recognised in its system are more complex (Kiziukiwicz 2014). The aspect that should be taken into consideration while discussing budget accounting is the principle of book-keeping records. The cash method is a form of presentation, execution and control of the execution of budget tasks, which is valid in the Polish law. Planned and executed income as well as expenditure constitute only such figures which were deposited into the account or spent in a particular budget year. Budget - in a tangible approach - a plan of tasks which have to be performed both as income and expenditure - is not equivalent with the real crediting or liability to the budget, whereas budget execution comprises only such expenses that were settled and only that income which was credited to the budget account. Practically, it results in the fact that in the tangible approach, the task is performed whereas in the cash method - it is not, which is reflected in the reports from the budget execution.

The rule is concise and easily accessible. It is suitable to draw up a traditional budget and to exercise budgetary powers given to particular decision-makers. The cash method is relatively simple from a technical point of view. It is not connected with subjective opinions and does not include preliminary estimates.

Despite all the benefits of the cash basis presented above, a lot of authors think that it is necessary to get rid of it in favor of the accrual basis.

The most serious drawback of the cash basis is, according to many authors, the possibility to manipulate the budget result. The existence of the possibility does not encourage people to manage funds intended to cover expenditure in a given budget year in a rational way. It results from the fact that accounting conducted according to the cash basis does not generate information concerning the state of the liabilities. It leads to lack of the possibility to determine the level of maturity in subsequent years, which results in the apparent decrease of the budget deficit in a given year.

Information concerning the costs of functioning of a unit are the most important to make management decisions. Without it, it is impossible to conduct any economic activity. Costs reflect the quality of work at all segments of the organization activity. The problem of incurring and implementing costs is a basic task of managers in each organization. Budgetary accounting conducted in accordance with the cash basis does not give any possibility to calculate costs of the provided services, nor does it make it possible to determine general operational costs of a unit. Accounting books include payments made, regardless of the fact whether they concern the costs of the period. According to the quoted Act on particular accounting rules, units of territorial government draw up the profit-and-loss account in a comparative version. The consequence includes the necessity to record costs by nature. Costs accounted by nature allow us to achieve information concerning the size of aggregated consumption of production factors in a particular period in the cross-section of simple, homogenous and indivisible costs. Cost records by cost nature is sufficient for reporting purposes, however, to make appropriate management decisions in the units of the territorial government, it is too aggregated. It may lead to the increase of the possibility of making mistakes during cost budgeting and may lower the effectiveness of the system of providing information. To be able to contribute to the increase of usefulness of information concerning the costs from budget accounting, it would be necessary to develop the system of cost reports. It is a very costly process which may meet many obstacles in a unit of the territorial government due to the specifics of its financing. A limited amount of financial means requires actions which will bring appropriate effects and which are not a financial burden for the units. The solution may be an analytical structure of cost records by cost nature, in which the structure of costs by nature would be developed in such a way to make decision-making processes easier. The introduction of the system of cost records by cost function and the use of record solutions could contribute to the obtaining of detailed information essential for the appropriate process of making management decisions. It would be possible to distinguish responsibility centers which would have tasks allocated to them as well as funds provided for their execution. It would also be possible to make a person who has proper qualifications responsible for the activity. It 


\section{ENTREPRENEURSHIP AND SUSTAINABILITY ISSUES}

ISSN 2345-0282 (online) http://jssidoi.org/jesi/

2020 Volume 7 Number 3 (March)

http://doi.org/10.9770/jesi.2020.7.3(37)

would lead to obtaining information on costs of supplies, production, sale and management. The advantages and disadvantages of the suggested solutions in the system of accounting and their influence on the process of making decisions are presented in the further part of the elaboration (A.J. Kozuch, M.Wakuła, 2012).

The cash basis does not provide any stimuli to use fixed assets in an effective way. It is caused by the the same treatment of costs concerning employment and capital expenditure. The fact that the latter will be productive throughout many years is omitted.

The disadvantages presented above show that it is impossible to present costs connected with operational activity of a unit in a given reporting period in a reliable and credible way. It is also not possible to measure the costs of provided services and evaluate the results of the unit's activities.

According to R. Guerrea de Souse (Gurrera de Sousa, 2013), the cash accounting can be characterised as easy to conduct, highly objective and limited in choices. The fault of the system includes divergences between income and expenditure, which may disturb the records of real costs of activities and do not confirm income in a proper way.

On the basis of the above deliberation, it can be stated that accounting conducted according to the cash basis does not provide enough information to make appropriate management decisions and makes it impossible to evaluate effectiveness of the activities performed.

Here, it is advisable to ask a question why, despite so many flaws of the accounting system of the cash basis, this model is still used in units of a territorial government? While answering the question, it is essential to take into account numerous factors including: resistance to changes or lack of qualified staff.

The antidote to the abnormalities resulting from the application of the cash method in communes may be the introduction of the obligatory accrual basis in accounting records. The European Commission is also in favour of its introduction suggesting the development and implementation of Accounting Standards in the Public Sector (the European Commission, 2013, Nowak, 2015). Such a solution would be helpful while conducting all the comparative analyses taking into account the effectiveness of spending funds on the same tasks by particular units of member countries at all levels (Szołno, 2017). Similarly, the tendency to shift from the cash method to the accrual basis is noticeable on the international scene. That solution was chosen by self-governments of such countries as: Switzerland, the Netherland, Sweden, Spain, Great Britain, Finland, Italy and Germany (Luder, Jones, 2003). A higher usefulness of the accrual basis in the budgetary accounting was confirmed by the research results conducted by Andriani Y., Kober R., (2010), Cohen S., Karatzimans S., (2017). The analyses conducted by Agriyanto R., Rohman, A., Ratmono D. and Ghozali, I. proved that the implementation of the budgetary accounting in City Government Semarang significantly and positively influenced the process of making decisions.

Results of the research conducted in Portuguese communes by De Silva, Nogueira SPS confirmed the fact that internal policymakers started to notice the significance of information derived from the system of accounting and reporting. The accrual basis existing in the units increased the quality of information and significantly influenced the relevance of making decisions.

As early as in the 1980s, Switzerland introduced the accrual basis of accounting to the public sector. On the basis of the research conducted by Bergamnn (2012), it can be stated that information taken from the accrual accounting was used while making decisions concerning internal control and setting goals of fiscal policy. The author cooperating with Fuchs and Brrusca I (2017) carried out research in 15 Swiss territorial self-governments. It aimed at evaluating the influence of the reforms of the accrual basis on financial reporting and determining the influence of new information on decision-making processes. The achieved results showed that the accrual 


\section{ENTREPRENEURSHIP AND SUSTAINABILITY ISSUES}

ISSN 2345-0282 (online) http://jssidoi.org/jesi/

2020 Volume 7 Number 3 (March)

http://doi.org/10.9770/jesi.2020.7.3(37)

reporting was a significant instrument to achieve dynamic local finance. The research also revealed that accrual accounting reforms were a significant starting point for a more strategic use of newly obtained financial data.

The accrual accounting in the public sector was also introduced by Indonesia. The country reformed its system of accounting and reporting by introducing the system of reporting called 'cash towards accruals'. On the basis of the research conducted by Mir M., Harun H., and Sutiyono, W. (2019) in 5 local self-governments of Indonesia, it can be stated that the implementation helped local authorities to obtain reports containing complete information.

Nakmahachalasint, O. and Narktabtee, K. (2019) in their research conducted in Thailand showed a number of problems encountered by the country while implementing the system of accrual accounting. They specified the most important ones including the resistance of the employees of the public sector, lack of understanding of the significance of information derived from the system of accrual basis of accounting as well as lack of informational materials on the topic.

Very interesting results were provided by the research conducted by Cuadrado-Ballesteros, B., Cito, F. and Bisogno, M.(2019) in 33 self-governments of countries of the Organization for Economic Cooperation and Development between 2010 and 2014. On the basis of the results, it can be stated that reforms in the public sector aiming at the implementation of the accrual basis of accounting contributed to the weakening of corruption, which was a problem in many countries. The introduction of the method weakened the information advantage of politicians over citizens.

The basic source of information on the situation in units of the territorial government is reporting of a local government unit which includes financial reports and budgetary reports.

To present the current condition of reporting of a unit of the territorial self-government and to evaluate it, it is necessary to classify the recipients of the information and their information needs. According to K. Winiarska, the form of reporting results from information needs of the surrounding and is determined by particular legal acts (Winiarska, 2016).

According to A.D. Riahi-Belkaoui, information users on communes are resource providers, tax-payers, loantakers, non-financial resource suppliers, employees, members and donors, users of the products provided by a unit, subjects responsible for the policy and for the supervision and evaluation of unit managers, i.e. the competent regulatory authorities and supervisory bodies, unit managers who are not business-oriented (RiahiBelkaoui, 2004).

M. Jastrzębska claimed that users of information on basic units of the territorial government were: government and its bodies, regional and local authorities, members of local communities, private entrepreneurs, potential investors, lenders and borrowers, employees and their trade unions, service providers and their business partners taking part in performing tasks of a unit of the territorial government (Jastrzębska, 1999).

On the basis of the deliberation mentioned above, recipients of information on communes can be divided into two groups. One of them consists of external recipients (citizens and business units). The other group includes internal ones (the authorities of a basic units of the territorial government).

It should be emphasised that each of the users of external reporting has various information needs. According to W.A. Nowak (2014) they may include: types and values of material fixed assets, consumption of the fixed capital, social programs conducted and tax liabilities. 


\section{ENTREPRENEURSHIP AND SUSTAINABILITY ISSUES}

ISSN 2345-0282 (online) http://jssidoi.org/jesi/

2020 Volume 7 Number 3 (March)

http://doi.org/10.9770/jesi.2020.7.3(37)

The information needs of the government and its bodies as well as other self-governments are fulfilled by external reporting which has the uniform form regulated by national and international laws (Firkowska-Jakobsze, 2017). In K. Winiarska's opinion, they are differentiated according to the type of recipients, scope, the degree of details and their frequency (2016).

As far as fulfillment of the information needs by other users of reporting drawn by communes is concerned, A. Adamek-Hyska (2013) claimed that they should have the form of a non-uniform report. Thus, the commune authorities should adapt the reporting model and management tools in such a way to make it possible to fulfill their needs. The current regulations concerning reporting of communes do not require their entities to implement the tools of management accounting facilitating the process of making decisions and the evaluation of the achievements. It proves that accounting of basic units of the territorial government and their reporting is focused mainly on the fulfillment of the legal duties, which fully fulfill only the needs of government agendas for control and statistics purposes. It is one of the most important dysfunctions of the existing reporting (Wakuła, 2015).

Shortage of information reporting made by units of the territorial government was noticed by the research carried out by other authors (Filipiak, 2009, Walińska, Bek-Gaik, Rymkiewicz, 2015). They advised aiming at improving the structure and information content of reporting to fulfill the needs of various stakeholders. Z. FirkowskaJakobsze (2017) did not agree with the view presented by K. Winiarska (2016) that financial reports of units of the sector of the public finance were the source of data necessary to make financial decisions contributing to the optimal management of the public financial means and to the achievement of the best results from particular expenditure. It resulted from the fact that the aim of making each financial report by any unit is mainly to provide their recipients with information concerning economic and financial processes taking place in a given economic unit that may influence their material position and financial economy as well as may be the basis for making decisions in a wider scope.

Another barrier negatively influencing the full use of budgetary reporting for management purposes is the cash basis applied in the accounting of units of the territorial government. The cash method of reporting economic operations does not include numerous economic events. The consequence is the fact that reporting lacks events and economic processes which are not connected with a direct cash method. It should also be emphasized that budgetary reporting includes means which has not been credited to the budget bank account, for instance, shares in tax which are the income of the state budget. However, the information does not include means which are on the bank account of a unit and concern the following year (for example, a January rate of the general education subsidy) (Filipiak, 2009). Effective management of a unit of the territorial government and the proper evaluation of the financial situation may interrupt the statutory deadlines of making budgetary reports. It leads to the delay in terms of presenting the state of realization of the budget processes which take place during the implementation of the budget. The dysfunction of the budget reporting is lack of financial stability between particular periods. It results from the fact that territorial governments do not make reports concerning cash flows. Units of the local governments do not have such a possibility to evaluate the real influence of liabilities on their financial situation. The current liability account classifies credits, loans and securities as debt omitting unmatured liabilities.

\section{Research results}

The communes of Siedlce subregion and Ostrołęka subregion. The choice of the area was dictated by their specifics. They are part of the Masovian province described as the voivodship of the greatest contrasts. General indicators calculated for the whole province do not reflect the real situation in the studied subregions. To characterise the studied subregions, the following features were selected:

- Total income in PLN per capita, 
- The number of economic entities

- The number of inhabitants,

- Population per $\mathrm{km}^{2}$,

- The area in $\mathrm{km}^{2}$

Analyses on the basis of the above features were conducted using standard measurement: minimal and maximal value, the median, variation coefficient. The results are presented in Table 1.

Table 1. Characteristics of the studied communes.

\begin{tabular}{|l|c|c|c|c|c|}
\hline \multicolumn{1}{|c|}{ Characteristics } & N & Me & Min & Max & V \\
\hline Total income in PLN per capita & 88 & 4294,40 & 3630,22 & 6660,16 & $9,6 \%$ \\
\hline The number of economic entities & 88 & 622 & 194 & 7801 & $115,1 \%$ \\
\hline The number of inhabitants & 88 & 5276 & 1679 & 22656 & $61 \%$ \\
\hline Population per km & 88 & 40 & 19 & 1071 & $201,6 \%$ \\
\hline The area in $\mathrm{km}^{2}$ & 88 & 119 & 10 & 371 & $45,6 \%$ \\
\hline
\end{tabular}

Source: Own elaboration on the basis of the data from Local Data Bank

On the basis of the data presented in Table 1, it is possible to state that half of the studied units achieve income per capita at 4294,40 PLN and lower. The lowest income per capita amounted to 3630,22 PLN and the highest 6660,19 PLN. The lowest number of economic entities in a commune was 194 and the highest -7801 . Half of the studied communes have at least 5276 inhabitants. Maximal number of inhabitants in one of the studied communes amounted to 22656. The lower area of the commune in Siedlce subregion and Ostrołęka subregion is $10 \mathrm{~km}^{2}$.

While evaluating diversity of the presented characteristics in the studied communes using the coefficient of variance for measures of location, we can state that nonuniform features of the analysed communes include: population per $1 \mathrm{~km}^{2} 201,6 \%$, the number of economic entities $115,1 \%$, the number of inhabitants $61 \%$ and the area in $\mathrm{km}^{2} 45,6 \%$.

The conducted research was addressed to heads of communes, treasurers and secretaries. It aimed at getting to know the applied methods and accounting tools implemented to increase the efficiency of managing available resources. 89 surveys were conducted and the responses were provided by 15 secretaries and 73 treasurers (only in one commune, it was possible to carry out a survey both with the secretary and the treasurer). Heads of the communes, when asked to answer the questions in the survey, delegated the task to secretaries pointing at their competence.

The respondents were first asked about the development of their professional careers. On the basis of the research, it can be stated that $86 \%$ of the secretaries worked in the public sector at the beginning of their careers, the others started their professional path in the private sector. Analysing work experience of the secretaries, it can be pointed out that $67 \%$ of them were connected with the public sector at the beginning of the career. The other $33 \%$ worked in the private sector before the started work in communes. It may have an influence on the process of dissemination of solutions and tools from the private sector to the public one.

The practice of accounting and the applied method of accounts have a significant influence on information values of reporting. The studied units of the territorial government apply the cash basis (75\% of the analysed units). Due to the fact that the method is widely criticised, the conducted research made an attempt to examine the opinion of 


\section{ENTREPRENEURSHIP AND SUSTAINABILITY ISSUES}

ISSN 2345-0282 (online) http://jssidoi.org/jesi/

2020 Volume 7 Number 3 (March)

http://doi.org/10.9770/jesi.2020.7.3(37)

the respondents concerning the cash basis. The results were quite surprising. Only $9 \%$ of the respondents noticed the necessity to shift to the cash method to improve the quality of information generated by the accounting system. It confirmed the thesis which was mentioned in the theoretical part of the article that employees of the local government were resistant to any changes and were not aware of the importance of information derived from the reports. $51 \%$ of the respondents claimed that changes in the classification structure were the main element aiming at the improvement of the accounting system. The current budgetary classification does not require to calculate indirect costs. Due to that, no attention is paid to the areas where costs occur and, as a consequence, there is no possibility to calculate real costs concerning the particular cost object.

While analysing the research concerning the possibilities of using financial reporting in making decisions, $72 \%$ of the respondents stated that the existing system provided a wide range of information necessary for the management. The results of the study did not confirm the thesis indicated in the introduction. Such a distribution of responses may be caused by the fact that the answers were given only by treasurers who also had access to other data that could be used while making decisions. It may lead to the conclusion that current reporting needs changes which would enable the use of this additional information that are used by budget accountants. Despite the fact that almost three-quarters of the respondents claimed that the existing system of accounting and reporting was fully functional, there were still $23 \%$ who admitted to making additional reports, different from those obligatory. It confirmed the fact that the existing reporting system did not appeal to them fully. An interesting fact was mentioned by $12 \%$ of the respondents. They claimed that the reporting system of the communes gave them limited possibilities of providing information used while making decisions. It was a very significant postulate as it showed the need to introduce changes for the purpose of fulfilling the needs of the studied communes. While analysing the responses to the studied question in comparison with the career development report, it can be stated that $68 \%$ of the respondents who claimed that the current reporting did not fulfill their information needs worked in the private sector earlier. The results of the analyses conducted by the author were completely different from the ones achieved by B. Filipiak (2009). In the quoted research, only 39,3\% of the respondents thought that existing reporting provided full scope of information essential in the process of making decisions.

The main goal of the reporting in the studied communes was fulfilling legal duties (99\%). As many as $68 \%$ of the respondents made reports for management purposes, whereas $75 \%$ did it to fulfill the needs of banks, other territorial governments and inhabitants. Only $8 \%$ of the surveyed people claimed that the main beneficiaries are the inhabitants and $20 \%$ pointed out banks. Others mentioned Regional Chamber of Audits, Statistics Poland, the Marshal Office and the Ministry of Finance as the beneficiaries. According to the respondents, the main faults concerning the reporting included:

- lack of comparability resulting from frequent changes in the legislation (74\%)

- lack of inclusion of events and economic processes that are not directly connected in the cash method of accounting (20\%)

- lack of information on the costs $(9 \%)$

It is a very worrying fact that only $9 \%$ of the respondents claimed that the existing reporting lacked information on costs. It is significant as far as conducting rational financial economy and efficient management are concerned. To obtain such information, it would be necessary to broaden the existing scope of costs records.

As many as 54 units apply only and solely accounts under group 4 for cost records. In 17 communes, budget accounting is carried out only from the perspective of budget reporting, and in 3 of them, the secretaries could not determine the way of cost records. Despite the fact that it is obligatory to draw up a profit-and-loss account in a comparative form, the legislator does not forbid to record costs in a functional way. The Ordinance of the Minister of Development and Finance of 13 September 2017 on accounting and plans for accounts of the state 


\section{ENTREPRENEURSHIP AND SUSTAINABILITY ISSUES}

ISSN 2345-0282 (online) http://jssidoi.org/jesi/

2020 Volume 7 Number 3 (March)

http://doi.org/10.9770/jesi.2020.7.3(37)

budget, budgets of units of the local self-government, budget entities, local budgetary entities, state-run specific purpose funds as well as public budgetary entities established outside the territory of the Republic of Poland provides a list of accounts 5, which enable costs to be grouped according to place of their incurrence, which in turn makes calculating costs easier. 36 communes of Siedlce subregion and Ostrołęka subregion apply costs which are recognized by nature and by function. None of the analysed units uses only the 'by function' model. The result is alarming and means that only $35 \%$ of the studied communes apply multi sectional cost record. It also confirms the fact that very few respondents are aware of the information capacity of the record. Comparing the results of the research conducted by B. Filipik in 2009, it it necessary to emphasize that the awareness of the significance of the information has been growing over the years. The analyses mentioned above show that only $3,8 \%$ of the units of the local self-government took into account the division of costs into types of the conducted activity.

\section{A suggestion of changes in the cost records of unit of the territorial government}

As it was mentioned above, the information on costs has a basic meaning while making decisions concerning the functioning of an economic unit. To achieve full and reliable information on the deliberate use of resources in a commune, it would be essential to develop systems of the records of costs. This part of the elaboration deals with 3 aspects of accounting solutions which may help to adjust accounting systems. The following models may be suggested:

- Cost accounting by cost nature with detailed task accounts,

- Cost accounting by responsibility centers (according to the places where the costs occur)

- Cost accounting both by cost nature and by cost function.

Cost accounting by cost nature is based on the following cost accounts: depreciation, material and energy consumption, third-party services, taxes and charges, remuneration, social security and other contributions as well as other expenses by nature.

Detailed accounting in the team is conducted according to the classification points of the financial plan and in cross-sections adjusted to the planning needs, analyses and in such a way to make it possible to draw up a financial statement.

To obtain information concerning costs of performing a particular budget task, it would be essential to introduce an additional analysis enabling recording costs for particular tasks. The advantages of the suggested model include:

- The possibility to use already defined billing accounts for the needs of recording costs in cross-sections connected with performing budget tasks.

- Providing consistence of recording costs in budget classification and task classification.

- The possibility of multitask analysis. The solution enables us to collect information concerning budget tasks and provides data on budget classification according to which a particular budget task is performed and costs involved in it.

The flaw of the solution, however, is the increase in the number of accounting records. it is caused by the fact that current accounting records made by details connected with budget classification must be additionally fragmented into particular budget tasks.

While analysing such cost records in a particular unit of a territorial government, the following example may be used:

A unit of the territorial government analyses a specific budget task. The comparison of two budget periods shows that task costs increased by $22 \%$ with the same scope of provided services. The answer why something like that occurred would be difficult without the comparison of task costs and costs recorded by nature. Conducting records according to the suggested model gives the possibility to conduct the analysis of particular budget tasks 
in terms of costs influencing a given task. Assuming that fulfilling a task requires the following costs: remuneration of the employees, social security and other benefits to the employees, third-party services as well as taxes and charges. The comparative analysis indicated that all the costs except for taxes and charges increased by 3\%, whereas costs connected with perpetual usufruct charges (classified as taxes and charges) went up by $35 \%$ as a result of updating the annual fee. The table 2 illustrates it:

Table 2. Costs of the fulfillment of the budget task in a particular unit of the territorial government

\begin{tabular}{|l|c|c|c|}
\hline \multirow{2}{*}{ Task costs } & \multicolumn{2}{|c|}{ Level } & \multirow{2}{*}{ Dynamics 2017=100 } \\
\cline { 2 - 4 } & \multicolumn{2}{|c|}{ Years } \\
\cline { 2 - 4 } & $\mathbf{2 0 1 7}$ & 188490 & 103 \\
\hline Remuneration & 183000 & 37698 & 103 \\
\hline Social security and benefits to the employees & 36600 & 1854 & 103 \\
\hline Third-party services & 1800 & 494100 & 722142 \\
\hline Taxes and charges & 366000 & 587400 & 722 \\
\hline
\end{tabular}

Source: Own elaboration

Owing to such information, the head of a unit of the territorial government has knowledge on the factors shaping the level of costs of the performed tasks and on the basis of it, they can make management decisions.

Another suggested method of costs records aiming at a full and reliable information used in managing a basic unit of the territorial government is cost accounting by responsibility centres, which is according to the places where they occurred. The places of occurrence of costs in a commune are regarded as identified sectors of the unit activities for which costs are recorded, such as branches, departments or organizational entities of a commune conducting particular budget tasks. The benefits of such a system of recording the consumption of targeted resources include:

- the possibility to analyse the unit activity in terms of costs produced by particular areas. It provides the management with information on the most costly areas of the unit activity. Without such a separation, the only information provided would be on the general level of costs incurred. However, it would not give the answer to the question on which areas of the activity required costs are most significant and where restructuring measures need to introduced.

- It considerably allows cost allocation to particular budget tasks. The cost allocation means assigning expenses to particular budget tasks. It occurs when the common costs are generated, the ones which concern many tasks and which are essential to fulfill the task.

- The possibility to compare particular sectors in terms of cost carriers.

The usefulness of the model of cost records will be presented using the following example.

Due to a lack of full financing of a unit in the following budget year, the head of the unit decided to make a decision to restructure the costs. The costs in the given unit looked as follows (Table 3):

Table 3. The cost level connected with the fulfillment of the budget task 
ENTREPRENEURSHIP AND SUSTAINABILITY ISSUES

ISSN 2345-0282 (online) http://jssidoi.org/jesi/

2020 Volume 7 Number 3 (March)

http://doi.org/10.9770/jesi.2020.7.3(37)

\begin{tabular}{|l|c|c|}
\hline \multicolumn{1}{|c|}{ Costs of the task } & Level & Cost share \\
& [\%] \\
\cline { 2 - 2 } & Year & \\
\cline { 2 - 2 } & $\mathbf{2 0 1 8}$ & \multirow{2}{*}{72,8} \\
\hline Remuneration & 4500000 & \multirow{2}{*}{14,5} \\
\hline Social security and benefits to the employees & 900000 & \multirow{2}{*}{11,4} \\
\hline Third-party services & 700000 & \multirow{2}{*}{1,3} \\
\hline Taxes and charges & 80000 & 100 \\
\hline TOTAL & 6180000 & 100 \\
\hline
\end{tabular}

Source: Own elaboration

On the basis of the data in the table, it can be stated that the most significant costs in the analysed commune are the ones connected with the employment. Remunerations and social security altogether make up $87,3 \%$ of the costs of fulfilling a budget task. The attempts concerning restructuring costs connected with third-party services or taxes and charges surely won't be sufficient due to their little significance in total costs. The head of the unit will have no choice but to take measures to lower the employment costs. To be able to do it properly, the head of the unit should support his / her decision with the analysis of remuneration costs in particular organizational bodies.

Table 4. Costs of remunerations connected with fulfilling a budget task in particular organisational bodies of a unit of the territorial government.

\begin{tabular}{|c|c|c|c|c|c|c|}
\hline \multirow[t]{2}{*}{ Costs } & Year & \multirow[t]{2}{*}{ Department A } & \multirow[t]{2}{*}{ Department B } & \multirow[t]{2}{*}{ Department $\mathrm{C}$} & \multirow[t]{2}{*}{ Department D } & \multirow[t]{2}{*}{ Department E } \\
\hline & 2018 & & & & & \\
\hline Remuneration & 4500000 & 900000 & 1200000 & 400000 & 1400000 & 600000 \\
\hline $\begin{array}{l}\text { Benefits to the } \\
\text { employees }\end{array}$ & 900000 & 180000 & 240000 & 80000 & 280000 & 120000 \\
\hline Total & 5400000 & 1080000 & 1440000 & 480000 & 1680000 & 720000 \\
\hline $\begin{array}{l}\text { The share of places of } \\
\text { cost occurrence in } \\
\text { total costs [\%] }\end{array}$ & 100 & 20 & 26,7 & 8,8 & 31,2 & 13,3 \\
\hline
\end{tabular}


ENTREPRENEURSHIP AND SUSTAINABILITY ISSUES

ISSN 2345-0282 (online) http://jssidoi.org/jesi/

2020 Volume 7 Number 3 (March)

http://doi.org/10.9770/jesi.2020.7.3(37)

\section{Source: Own elaboration}

The data included in the table 4 indicate the Body B and Body D are the most costly organizational units as they generate $51 \%$ of remuneration and derivatives in total. Due to that, it would be necessary to analyse employment in the areas. The action will bring the fastest financial effect. Without a detailed cost records concerning the places of their occurrence, the quality of information will definitely make it harder to make decisions.

The example presented above showed the analysis of the most significant areas in a unit as far as generating costs is concerned. Owing to the application of cost recording according to the places of their occurrence, it is possible to calculate costs of employment of a person. Without such a way of recording costs, it would not be possible. It is illustrated by the Table 5 below.

Table 5. Cost of employment of ona person in a given organisational body.

\begin{tabular}{|c|c|c|c|c|c|c|}
\hline \multirow[t]{2}{*}{ Costs } & Year & \multirow[t]{2}{*}{ Department A } & \multirow[t]{2}{*}{ Department B } & \multirow[t]{2}{*}{ Department C } & \multirow[t]{2}{*}{ Department D } & \multirow[t]{2}{*}{ Department E } \\
\hline & 2018 & & & & & \\
\hline Remuneration & 4500000 & 900000 & 1200000 & 400000 & 1400000 & 600000 \\
\hline $\begin{array}{l}\text { Benefits to the } \\
\text { employees }\end{array}$ & 900000 & 180000 & 240000 & 80000 & 280000 & 120000 \\
\hline Total & 5400000 & 1080000 & 1440000 & 480000 & 1680000 & 720000 \\
\hline $\begin{array}{l}\text { Employment } \\
\text { calculated as full-time } \\
\text { contracts }\end{array}$ & 128 & 20 & 36 & 12 & 43 & 17 \\
\hline $\begin{array}{l}\text { Average cost per one } \\
\text { emploee }\end{array}$ & 42187,5 & 54000 & 40000 & 40000 & 39069,8 & 42352,9 \\
\hline $\begin{array}{l}\text { Average cost per one } \\
\text { month }\end{array}$ & 3515,6 & 4500 & 3333,3 & 3333,3 & 3255,8 & 3529,4 \\
\hline
\end{tabular}

Source: Own elaboration

The analysed system of cost recording is connected with determining the centers of cost responsibilities. Cost recording according to particular organizational bodies may be linked with determining responsibility for the costs generated on a given area. After the introduction of responsibility connected with a relevant motivation system, it is possible to achieve results in a form of cost savings or an increased effectiveness.

Another model of cost recording, which will influence the quality of making decisions in units of territorial government, may be the one based on cost accounting by cost nature (Group 4) and by cost function (Group 5). Group 5 deals with records and the settlement of costs by function. Accounts of the group should be applied in such a case in which the character and the scope of the activity or organization of the unit require the determination of the structure of costs for particular types and kinds of its activity. The group includes such accounts as: normal business expenditure, auxiliary activity costs, management costs and the settlement of the activity costs. 


\section{ENTREPRENEURSHIP AND SUSTAINABILITY ISSUES}

ISSN 2345-0282 (online) http://jssidoi.org/jesi/

2020 Volume 7 Number 3 (March)

http://doi.org/10.9770/jesi.2020.7.3(37)

\section{Conclusions}

The theoretical elaboration conducted above confirmed the fact that there are numerous dysfunctions existing in the current accounting and reporting applied in the units of territorial self-government. The main one is the cash basis. While using the method, it is not possible to receive reliable information concerning the budget balance and complete information on costs. The cash method does not induce users to manage the available resources effectively. On the international arena, it is postulated to shift from the cash basis into the accrual method. Polish communes, however, often face numerous obstacles. It was confirmed by the research conducted in communes of Siedlce subregion and Ostrołęka subregion. Only $9 \%$ of the respondents noticed the need of change from the cash basis into the accrual method of reporting, whereas as many as $74 \%$ claimed that the existing form of reporting is sufficient to make appropriate decisions. It is worrying that only $9 \%$ of the respondents pointed out lack of information of the consumed resources as the main flaw of the reporting.

The results of the conducted research may indicate that commune management uses information from the accounting system in a limited degree while managing a commune. It is concentrated only and solely on the control of the limits concerning budget expenditure. Lack of classification of expenses by function may indicate that a detailed calculation of the performed services and realized public tasks is not conducted.

\section{References}

Adamek-Hyska, A. (2013). Budget reporting as an element of finance management in a unit of the territorial government. (Sprawozdania budżetowe jako element zarządzania finansami $w$ jednostce samorządu terytorialnego)D, Zeszyty Naukowe Uniwersytetu Szczecińskiego nr 786. Finanse. Rynki Finansowe, Ubezpieczenia Nr 64: Szczecin. http://wneiz.pl/nauka_wneiz/frfu/64-2013/FRFU-64-t2-5.pdf

Agriyanto, R., Rohman, A., Ratmono, D. Ghozali, I. (2016). Accrual based accounting implementation: An approach for modelling major decisions. Risk Governance and Control: Financial Markets and Institutions, 6(4-special issue), 531-539. http://dx.doi.org/10.22495/rgcv6i4siart12

Andriani, Y., Kober, R. (2010). Decision Usefulness of Cash and Accrual Information: Public Sector Managers' Perceptions. Australian Accounting Review, 20(2), 144-153. https://doi.org/10.1111/j.1835-2561.2010.00087.x

Bergmann, A. (2012). The influence of the nature of government accounting and reporting in decision-making: Evidence from Switzerland. Public Money and Management, 32(1), 15-20, https://doi.org/10.1080/09540962.2012.643050

Cohen, S., Karatzimans, S. (2017). Accounting information quality and decision-usefulness of governmental financial reporting: Moving from cash to modified cash. Meditari Accountancy Research, 25(1), 95-113, https://doi.org/10.1108/MEDAR-10-2015-0070

Cuadrado-Ballesteros, B., Cito, F., Bisogno, M. (2019). The role of public-sector accounting in controlling corruption: an assessment of Organisation for Economic Co-operation and Development countries. International Review of Administrative Sciences, https://doi.org/10.1177\%2F0020852318819756

Da Silva Nogueira S.P.S, Jorge, S.M.F, Oliver. M.C. (2013). The usefulness of financial reporting for internal decision-making in Portuguese municipalities, Management Research, 178-21, https://doi.org/10.1108/MRJIAM-Dec-2011-0465

Da Silva Nogueira, S.P.S., Jorge, S.M.F. (2016). The perceived usefulness, of financial information for decision, making in Portugusse municipalities the importance of internal control. Journal of Applied Accounting Research, 18 (1), 116-136, https://doi.org/10.1108/JAAR$\underline{05-2014-0052}$ 


\section{ENTREPRENEURSHIP AND SUSTAINABILITY ISSUES}

ISSN 2345-0282 (online) http://jssidoi.org/jesi/

2020 Volume 7 Number 3 (March)

http://doi.org/10.9770/jesi.2020.7.3(37)

Dylewski, M. (2011). Dilemmas concerning long-term planning in units of the territorial government in the context of legal changes and experience of selected countries. (Dylematy w zakresie planowania długoterminowego w jednostkach samorządu terytorialnego w kontekście zmian ustawowych oraz doświadczeń wybranych krajów), Finanse- nowe wyzwania teorii i praktyki. Finanse publiczne. Prace Naukowe Uniwersytetu Ekonomicznego we Wrocławiu nr 173, Wydawnictwo Uniwersytetu Ekonomicznego we Wrocławiu, Wrocław, p. 83-93.

Efendi, R., Dewi, F.G., Gamayuni, R.R. (2018). Usefulness analysis of accrual based accounting information on local government financial statement: A qualitative study. International Journal of Scientific and Technology Research, 7(11), November, 10-21.

El Idrissi, N. E. A., Ilham Zerrouk, I., Naoual Zirari, N., Monni, S. (2020). Comparative study between two innovative clusters in Morocco and Italy. Insights into Regional Development, 2(1), 400-417. http://doi.org/10.9770/IRD.2020.2.1(1)

Filipiak, B. (2009). Methodology of the complex evaluation of financial economy of a unit of the territorial government. (Metodyka kompleksowej oceny gospodarki finansowej jednostki samorządu terytorialnego), Difin, Warszawa

Firkowska-Jakobsze, Z. (2016). The concept of an integrated financial report of a commune as a unit of the territorial government, doctoral dissertation. (Koncepcja zintegrowanego raportu finansowego gminy jako jednostki samorządu terytorialnego, rozprawa doktorska), Uniwersytet Łódzki, Łódź.

Fuchs, S., Bergmann, A., Brusca, I. (2017). Using financial reporting for decision making as a measure towards resilient government finances: The case of Switzerland. Lex Localis, 15(1), 133-153 https://doi.org/10.4335/15.1.133-153(2017)

Guerra de Sousa, R., Fernandes de Vasconacelos, A., Lira Caneca, R., Katsumi Niyama, J. (2013). Accrual basis accouting in the Brazilian public sector: empirical research on the usefulness of accouting information. Revista Contabilidade\&Financas, 24(63) Săo Paulo

Jaruga, A. (1988). Governmental Accouting, Auditing and Finacial Reporting in East Europen Nations, J.L. Chan, R.H. Jones, (Ed.), Governmental Accouting and Auditing International Comparison, Croom helm Ltd, London

Jaruga, A. (1988). Governmental Accouting, Auditing and Finacial Reporting in East Europen Nations, J.L. Chan, R.H. Jones, (Ed.) Governmental Accouting and Auditing International Comparison, Croom helm Ltd, London

Jaruga, A. (1990). Government Accouting in Poland, A Premchand, (Ed.) Government Finnancial Managemnet Issues and Country Studies, Internationak Monetary Fund, Press Washungton D.C.

Jaruga, A. (2001). The role of remedial accounting. (Rola rachunkowości zaradczej), Jaruga A., Nowak W.A., Szychta A., (Ed.) Rachunkowość zarządcza. Koncepcje i zastosowania. Absolwent Sp. z o.o. Łódź

Jaruga, A. (2007). Perspectives of the development of accounting in the light of a convergence of International Financial Reporting Standards. (Perspektywy rozwoju rachunkowości w świetle konwergencji Międzynarodowych Standardów Sprawozdawczości Finansowej), Cebrowska T., Kowalik A., Stępień R., (Ed.), Rachunkowość wczoraj, dziś i jutro, Stowarzyszenie Księgowych w Polsce, Warszawa.

Jastrzebska, M. (1999). Instruments for managing commune finance. (Instrumenty zarządzania finansami gminy), Samorząd Terytorialny, Wolters Kluwer Polska S.A., Warszawa, p. 15-25.

Kiziukiewicz, T. (2014). Accounting of units of the sector of public finance. (Rachunkowość jednostek sektora finansów publicznych), PWE, Warszawa.

Komisja Europejska. 2013. A report of 6 March 2013 for the Council and the European Parliament concerning the implementation of accounting standards of the public sector in member countries - the usefulness of IPSAS for member countries. (Sprawozdanie $\mathrm{z}$ dnia 6 marca 2013 r dla Rady i Parlamentu Europejskiego, w kierunku wdrożenia standardów rachunkowości sektora publicznego w państwach członkowskich - Przydatność MSRSP dla państw członkowskich), Bruksela.

Kożuch, A.J. (2013). Cost accounting as an instrument for effective meeting public demands of unit of the territorial government. (Rachunek kosztów jako instrument zapewniający sprawne zaspokojenie potrzeb publicznych w JST), Optimum, Studia Ekonomiczne nr $1(61), 93-105$.

Kożuch, A.J., Wakuła, M. (2012). Accounting as a source of information on costs in the process of managing a unit of the territorial government. (Rachunkowość jako źródło informacji o kosztach w procesie zarządzania jednostką samorządu terytorialnego), Acta Universitatis Nicolai Copernici, Zarządzanie XXXIX , Zzeszyt 407, Toruń: 97-108. http://dx.doi.org/10.12775/AUNC_ZARZ.2012.007 


\section{ENTREPRENEURSHIP AND SUSTAINABILITY ISSUES}

ISSN 2345-0282 (online) http://jssidoi.org/jesi/

2020 Volume 7 Number 3 (March)

http://doi.org/10.9770/jesi.2020.7.3(37)

Kożuch, A.J., Wakuła, M. (2012). Accounting as a source of information on costs in the process of managing a unit of the territorial government (Rachunkowość jako źródło informacji o kosztach w procesie zarządzania jednostką samorządu terytorialnego), Acta Universitatis Nicolai Copernici, Zarządzanie XXXIX, zeszyt 407 Toruń.

Lüder, K., Jones, R, (Ed..). (2003). Reforming Governmental Accouting and Budgeting in Europe, Fachverlag Moderne Wirtschaft, Frankfirt am Main.

Mir, M., Harun, H., Sutiyono, W. (2019). Evaluating the Implementation of a Mandatory Dual Reporting System: The Case of Indonesian Local Government. Australian Accounting Review, 29(1), 80-94, https://doi.org/10.1111/auar.12232

Nakmahachalasint, O., Narktabtee, K. (2019). Implementation of accrual accounting in Thailand's central government. Public Money and Management, 39(2), 139-147 https://doi.org/10.1080/09540962.2018.1478516

Nowak, W.A. (2014). Accounting of the sector of public finance as industry accounting. (Rachunkowość sektora finansów publicznych jako rachunkowość branżowa). Prace Uniwersytetu Ekonomicznego we Wrocławiu, (373), 182-194, http://dx.doi.org/10.15611/pn.2014.373.14

Nowak, W.A. (2015). Towards the standardisation of accounting of the public sector in the European Union. (Ku standaryzacji rachunkowości sektora publicznego w Unii Europejskiej). Prace Naukowe Uniwersytetu Ekonomicznego we Wrocławiu, 388, 148-158, http://dx.doi.org/10.15611/pn.2015.388.15

Riahi-Belkaoui, A. (2004). Accouting Theory, South-Western, Singapure.

Regulation of the Minister of Development and Finance on 13 September 2017 concerning accounting and account plans for the country budget, budgets of units of the territorial government, budget units, local budgetary departments, state earmarked funds and state budgetary units residing outside Poland . (Rozporządzenie Ministra Rozwoju i Finansów z dnia 13 września 2017 r. w sprawie rachunkowości oraz planów kont dla budżetu państwa, budżetów jednostek samorządu terytorialnego, jednostek budżetowych, samorządowych zakładów budżetowych, państwowych funduszy celowych oraz państwowych jednostek budżetowych mających siedzibę poza granicami Rzeczypospolitej Polskiej). Dz.U. 2017 poz. 1911

Szołno, O. (2017). Task budgeting in the context of the rules of effectiveness and efficiency of functioning of units of the territorial government. (Budżetowanie zadaniowe w kontekście zasad efektywności i skuteczności funkcjonowania jednostek samorządu terytorialnego). Prace Naukowe Uniwersytetu Ekonomicznego we Wrocławiu, 488, 255-265, http://dx.doi.org/10.15611/pn.2017.488.22

The act of 27 August 2009 on public finance, Journal of Laws of 2018, item 2500 with changes. (Ustawa z 27 sierpnia 2009 roku o finansach publicznych, Dz.U. 2018 poz. 2500 ze zmianami)

The act of 29 September 1994 on accounting, Journal of Laws, item 351. (Ustawa z 29 września 1994 roku o rachunkowości, Dz.U. 2019 poz.351)

Wakuła, M. (2015). The direction of changes in reporting in units of the territorial government. (Kierunki zmian w sprawozdawczości jednostek samorządu terytorialnego). Zeszyty Naukowe Uniwersytetu Przyrodniczo-Humanistycznego w Siedlcach, Seria Administracja $i$ Zarzadzanie, (1), s.205-216 https://repozytorium.uph.edu.pl/handle/11331/570

Walińska, E., Bek- Gaik, B., Gad, J., Rymkiewicz, B. (2015). Reporting of an enterprise as a tool for communication with the suuroundings. Financial and non-financial approach. (Sprawozdawczość przedsiębiorstwa jako narzędzie komunikacji z otoczeniem. Wymiar finansowy i niefinansowy), Wydawnictwo Uniwersytetu Łódzkiego, Łódź.

Wartalska, M. (2007). Financial economy of a city. Theory and case study. (Gospodarka finansowa miasta. Podstawy teoretyczne i studium przypadku), Wydawnictwo Uniwersytetu Łódzkiego, Łódź

Winiarska, K (Ed..). (2016). Financial and budget reporting of units of the sector of public finance. (Sprawozdawczość finansowa i budżetowa jednostek sektora finansów publicznych), Wolters Kluwer, Warszawa

Zysnarska, A. (2010). Budget accounting in the light of the concept of the true and correct view. (Rachunkowość budżetowa w świetle koncepcji prawdziwego wiernego obrazu), Wydawnictwo Uniwersytetu Gdańskiego, Gdańsk 
ENTREPRENEURSHIP AND SUSTAINABILITY ISSUES

ISSN 2345-0282 (online) http://jssidoi.org/jesi/

2020 Volume 7 Number 3 (March)

http://doi.org/10.9770/jesi.2020.7.3(37)

Monika WAKULA Ph.D, assistant professor in the Department of Management and Quality Sciences of Siedlce University of Natural Sciences and Humanities. Scientific interests: accounting and reporting of units of territorial self-government, managing finance of a commune

ORCID ID: orcid.org/0000-000-1-9896-7997

Register for an ORCID ID:

https://orcid.org/register

Copyright (C) 2020 by author(s) and VsI Entrepreneurship and Sustainability Center

This work is licensed under the Creative Commons Attribution International License (CC BY).

http://creativecommons.org/licenses/by/4.0/

c) (†) Open Access 